\title{
Immuno-histochemical study of the expression of Bcl-2 in the Leydig's interstitial cells and primary spermatocyte cells of adult male rabbit under the effect of oral Gossypol intake
}

\author{
Bassem S. Ahmed and Nasser M. Anwar" \\ From Departments of, Histology Al-Azhar Faculty of Medicine - Assuit and Pathology \\ Al-Azhar Faculty of Medicine - Cairo*
}

\begin{abstract}
Gossypol is a natural compound extracted from the seeds of some species of cotton plants (Gossypium species). Gossypol displays various drug properties, including male antifertility, antiproliferative activity on tumor cells (leukemia, prostate, adrenal, etc.) and endometriosis.

Recently, the action of gossypol has been thought to induce apoptosis in the target cells especially male testicular tissue. The current study was planned to evaluate the effect of oral intake of gossypol on the expression of anti-apoptotic Bcl-2 gene in the interstitial cells of Leydig and primary spermatocyte cells of adult rabbit.

Thirty adult male rabbits were used, subdivided into 5 equal groups. Group1 represented control group, groups 2, 3, and 4 represented rabbits intubated with $1.05 \mathrm{mg} / \mathrm{day}$ gossypol suspended in $1 \mathrm{ml}$. olive oil for 3,6 and 9 weeks respectively. Group5 rabbits were subjected to gossypol oral intake in the same manner for 9 weeks and were left for another 9 weeks as recovery periods.

All rabbits were sacrificed after $24 \mathrm{hrs}$ from last dose except group5 rabbits, testes were extracted fixed in neutral buffered formol and histologically processed for 5 um paraffin sections. Detection of Bcl-2 protein was done by using labeled streptavidin biotin technique with the monoclonal Bcl-2 antibody.

The evaluation of Bcl-2 expression in the interstitial cells of Leydig and primary spermatocyte cells, as an optical density, were done by the aid of image analysis system. The obtained data were statistically analyzed by using student t-test.

The study showed that there was a positive Bcl-2 expression in the interstitial cells of Leydig in all study groups, and there were statistically significant increase in the Bcl-2 expression in groups 2, 3 and 4 in comparison to control rabbits values $(\mathrm{p}<0.001)$. The recovery group rabbits showed a statistically significant decrease in the Bcl-2 expression $(\mathrm{p}<0.001)$ in comparison to control rabbits values.

The primary spermatocyte cells showed a very weak Bcl-2 expression in control group rabbits and rabbits of groups 2 and 3.

After 9weeks gossypol administration there was a positive Bcl-2 expression in some primary spermatocyte cells $(\mathrm{p}<0.001)$ and the overexpression of $\mathrm{Bcl}-2$ was continued in the recovery group rabbits $(\mathrm{p}<0.001)$.

The study concluded that gossypol may trigger Bcl-2 expression in interstitial cells of Leydig, which started after 2 weeks of oral administration and this effect is diminished after cessation of oral intake. Also there was an increase in Bcl-2 protein expression in primary spermatocyte cells after 9 weeks of oral gossypol intake and that increase persisted even after cessation of gossypol.

The study recommends further study about the role of gossypol on the relation between apoptosis inducing gene and apoptosis inhibiting gene in the testicular tissues.
\end{abstract}




\section{Bassem S. Ahmed and Nasser M. Anwar}

\section{Introduction}

Apoptosis is a process describing the common morphological changes that characterize the process of cellular self-destruction. Apoptosis is a normal cellular response to development, differentiation, and environmental stress. In eukaryotic cells, apoptosis could be initiated by changes in the endogenous endocrine state, tumor necrosis factors, exposure to hazardous chemical substances, and interruption in the cell cycle. These alterations trigger gene(s) expression that eventually results in cell death. The genes that regulate apoptosis have been subdivided into 2 major classes. The first class is anti-apoptotic gene family identified as Bcl-2 family, and second is favor programmed cell death (Bax, Bad and BclxS) family, (McDonnell, 1996).

The death promoting genes are functioned through the release of cytochrome-C, which is a cofactor for regulation of activation of latent enzymes named caspases. While the death preventing genes block the release of cytochrome-C (Minn et al 1998).

Apoptosis is involved in a typical pattern of changes in cellular morphology and biochemical constituents. The process started with a loss of cell junctions with all specialized membrane structures, the nuclear chromatin condensed and marginated into the nuclear margin. Subsequently, the nucleus splits into several distinct fragments and while the nucleus condenses a contraction of cytoplasmic volume occurs, membrane bleb develop and the cell transiently adopts a deeply convoluted outline before it finally breaks into discrete membrane bounded apoptotic bodies. (Savill et al 1999). All mechanisms involved in the cell size and shape changes is thought that depolymerization of actin activated by protein kinase $\mathrm{C}$, which is an essential for the profilic budding process that produce apoptotic bodies.

Gossypol, $\mathrm{C}_{30} \mathrm{H}_{30} \mathrm{O}_{8}$, is a natural toxin present in the cotton seed to protect it from insect damage. Gossypol exhibits multiple biological properties, including male antifertility activity, anticancer activity, and inhibition of numerous parasitic organisms' growth and antiviral activity against a number of enveloped viruses, including the AIDS virus (Mego, 2002).

Recently, gossypol has been shown to be active in inducing apoptosis in male spermatocytes and other lymphatic cells. Gossypol-induced apoptosis in spermatocytes is correlated with the reduction of protein kinase $\mathrm{C}$ basal activity and DNA fragmentation.

Because Cotton implantation is the main plant agriculture in Egypt and production of cotton has increased in the last few years. The use of crude cottonseed oil for cooking for human uses has also increased rapidly.

The aim of the present work was to study of the expression of $\mathrm{Bcl}-2$ in the interstitial cells of Leydig and primary spermatocyte cells of adult rabbit under the effect of oral intake of Gossypol.

\section{Materials and Methods Materials:}

A-The Drug

The pure gossypol was obtained as a 250mg vial from Sigma Chemical Corp. (Lot. $80 \mathrm{~K} 4082)$. The powder is water insoluble but soluble in ethanol or ether. It is stable at 2-8 ${ }^{0} \mathrm{C}$. The dose was calculated according to the human therapeutic dose after Paget's modification for rabbits.

The gossypol powder was suspended in pure olive oil as a vehicle and was shaking well before use.

\section{$B$-The Animal}

Thirty, 6months age, healthy adult male rabbits with average weight $1.5 \mathrm{Kg}$ were subjected to the study.

The rabbits were subdivided into 5 equal groups; Groupl (Control), Group2, Group3, Group4 and Group5.

Group1 rabbits were the healthy rabbits intubated orally with $1 \mathrm{ml}$ olive oil daily for 9 weeks and were considered as control group. 
Groups 2, 3, and 4 groups represented rabbits intubated with $1.05 \mathrm{mg}$ gossypol suspended in $1 \mathrm{ml}$ olive oil daily for 3,6 , and 9 weeks respectively.

Group5 represented rabbits treated with same protocol as experimental followed by 9 weeks recovery period after the last gossypol dose.

\section{The Methods:}

The rabbits of groups 1 to 4 were sacrificed after $24 \mathrm{hrs}$ after last intubation, while those of group5 were at the end of recovery period.

The testes were dissected and fixed in neutral buffered formol and processed for preparation of 5um paraffin section slides. Immuno-histochemical technique for detection of $\mathrm{Bcl}-2$ expression was performed using labeled streptavidin biotin technique (Zymed) Cat No. 18-0193 with the monoclonal antibody (Bcl-2).

The localization of $\mathrm{Bcl}-2$ protein was demonstrated as yellowish brown color area. (Pezzella et al., 1990)

Evaluation of Bcl-2 expression on the interstitial cells of Leydig's and primary spermatocyte cells of adult male rabbit were done by the aid of SuperEye Image analyzer system - HeidiSoft Corporation - Egypt as an optical density on 20 slide fields per rabbit (120 readings per group).

The obtained data were statistically analyzed using student t-Test for comparison between control and all other groups.

\section{Results}

Localization of Bcl-2 in the interstitial cells of Leydig (Plate-1, Table-1 and Figure-1)

The normal distribution of $\mathrm{Bcl}-2$ expression in the interstitial cells of Leydig in the control rabbit was shown in Plate 1-A. The mean optical density was 0.960 , SD was 0.191 and SEM was 0.043 .

After 3 weeks of gossypol oral intake there was an increased expression of Bcl-2 in the interstitial cells of Leydig Plate 1-B. The mean optical density was 1.269 , SD was 0.248 and SEM was 0.056. In comparison to control value there was statistically signifycant increase in Bcl-2 expression ( $\mathrm{p}<0.001)$.

The increase in the Bcl-2 expression in the interstitial cells of Leydig was continued in the 6weeks rabbits group Plate 1-C. The mean optical density was 1.399 , SD was 0.278 and SEM was 0.062 . In comparison to control value there was statistically significant increase in Bcl-2 expression ( $\mathrm{p}<0.001)$.

The marked increase in the Bcl-2 expression in the interstitial cells of Leydig was observed after 9weeks oral administration (Plate 1-D). The mean optical density was 1.428 , SD was 0.275 and SEM was 0.062 . In comparison to control value there was statistically significant increase in Bcl-2 expression ( $p<0.001)$.

In the recovery group rabbits there was a statistically significant decrease in the Bcl-2 expression in comparison to that of control group rabbits (Plate2-A). The mean was 0.737 , SD was 0.147 , SEM was 0.033 and ( $\mathrm{p}<0.001)$.

Localization of $\mathrm{Bcl}-2$ in the primary spermatocyte cells (Plate-2, Table-1 and Figure-2)

The Bcl-2 expression was negative in the primary spermatocyte cells of group1 (control), group2 (3weeks) and group3 (6weeks). The mean optical densities of Bcl-2 expression in the primary spermatocyte cells of groups 1, 2 and 3 were $0.349 \pm 0.069$, $0.333 \pm 0.066$, and $0.379 \pm 0.039$, respectively $(\mathrm{p}>0.05)$.

After 9 weeks oral gossypol intake some primary spermatocyte cells showed a marked positive $\mathrm{Bcl}-2$ expression $(\mathrm{p}<0.001)$ (Plate 2-B).

The mean optical density was 1.405 , SD was 0.280 and SEM was 0.063 .

The recovery group rabbits (group5) showed some primary spermatocyte cells with persistent positive Bcl-2 expression with statistically significance in comparison to controls $(\mathrm{p}<0.001)$ (Plate2-D).

The mean optical density was 1.471 , SD was 0.293 and SEM was 0.065 . 


\section{Bassem S. Ahmed and Nasser M. Anwar}

Table -1 Effect of gossypol oral intake on the Bcl2 expression on interstitial cells of Leydig and primary spermatocytes cells in the different study groups

\begin{tabular}{|c|c|c|c|c|c|}
\hline & Group1 & Group2 & Group3 & Group4 & Group5 \\
\hline \multicolumn{6}{|c|}{ Interstitial cells of Leydig (O.D.) } \\
\hline Mean & 0.960 & 1.269 & 1.399 & 1.428 & 0.737 \\
\hline SD & 0.191 & 0.248 & 0.278 & 0.275 & 0.147 \\
\hline SEM & 0.043 & 0.056 & 0.062 & 0.062 & 0.033 \\
\hline \multirow{2}{*}{ Test-Test } & & $\begin{array}{l}\text { Group2 vs } \\
\text { Group1 }\end{array}$ & $\begin{array}{c}\text { Group3 vs } \\
\text { Group1 } \\
\end{array}$ & $\begin{array}{l}\text { Group4 vs } \\
\text { Group1 } \\
\end{array}$ & Group5 vs Group1 \\
\hline & & $8.4 \mathrm{E}-05$ & $1.0 E-06$ & $2.7 \mathrm{E}-07$ & $1.8 E-04$ \\
\hline P-value & & $\mathrm{p}<0.001$ & $p<0.001$ & $\mathrm{p}<0.001$ & $p<0.001$ \\
\hline Significance & & Increase & Increase & Increase & Decrease \\
\hline \multicolumn{6}{|c|}{ Primary Spermatocytes (O.D.) } \\
\hline Mean & 0.349 & 0.333 & 0.379 & 1.405 & 1.471 \\
\hline SD & 0.069 & 0.066 & 0.039 & 0.280 & 0.293 \\
\hline SEM & 0.016 & 0.015 & 0.009 & 0.063 & 0.065 \\
\hline \multirow{2}{*}{ Test-Test } & & $\begin{array}{l}\text { Group2 vs } \\
\text { Group1 }\end{array}$ & $\begin{array}{l}\text { Group3 vs } \\
\text { Group1 }\end{array}$ & $\begin{array}{l}\text { Group4 vs } \\
\text { Group1 }\end{array}$ & Group5 vs Group1 \\
\hline & & 0.479 & 0.099 & $8.0 E-19$ & $4.5 E-19$ \\
\hline P-value & & $p>0.05$ & $p>0.05$ & $p<0.001$ & $p<0.001$ \\
\hline Significance & & NS & NS & Increase & Increase \\
\hline
\end{tabular}

N.B. 1-Number of readings was 20 fields per rabbit (total 600 readings)

2- $\mathrm{SD}=$ Standard deviation $\mathrm{SEM}=$ Standard error of mean $\quad \mathrm{t}$-Test=Student's T test $\quad \mathrm{p}$-value=Probability

3- O.D.=Optical Density 4- Statistical comparison was done vs control group data

5- $\mathrm{p}<0.05$ was considered as statistically significance $6-\mathrm{NS}=$ non significant

Figure-1 Effect of gossypol oral intake on the Bcl2 expression on interstitial cells of Leydig in the different study groups

o.D.

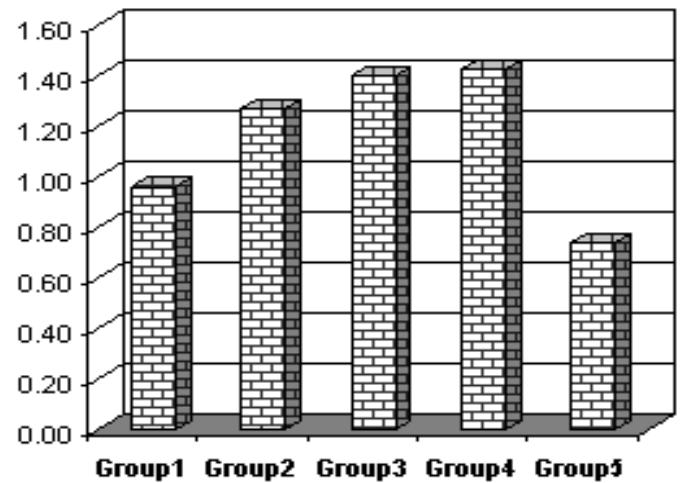

Figure-2 Effect of gossypol oral intake on the Bcl2 expression on primary spermatocytes in the different study groups

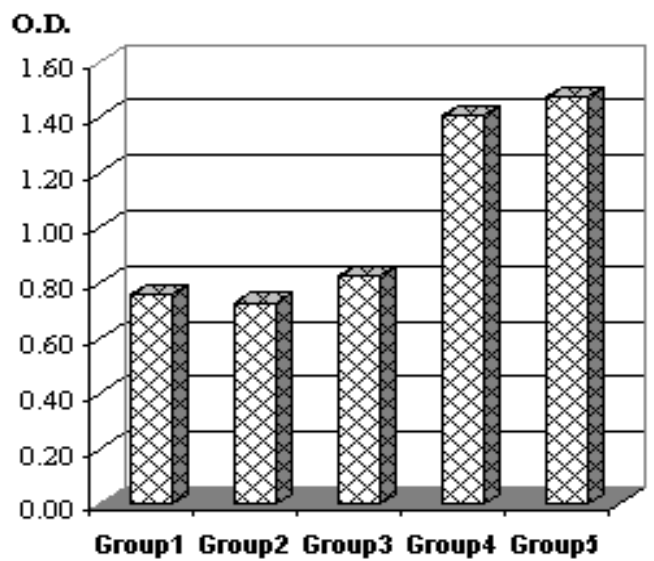




\section{Plate - 1}

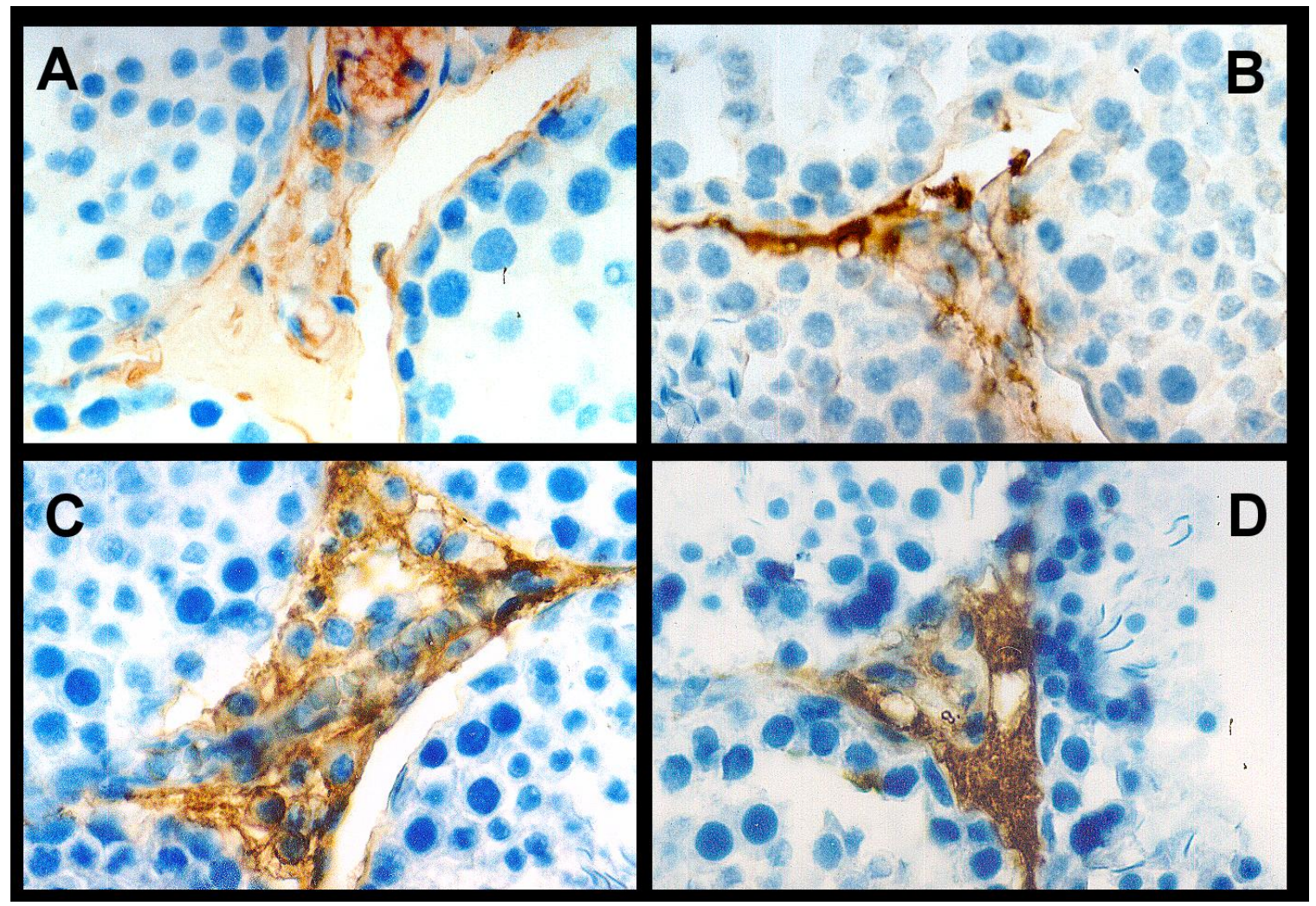

1-A A computerized photomicrograph of section in the testis of control group rabbits, showing the positive expression of $\mathrm{Bcl}_{2}$ in the interstitial cells of Leydig. (Immunostaining DAB, X630)

1-B A computerized photomicrograph of section in the testis of group2 rabbits, showing an increased expression of $\mathbf{B c l}_{2}$ in the interstitial cells of Leydig. (Immunostaining DAB, X630)

1-C A computerized photomicrograph of section in the testis of group3 rabbits, showing a marked increase in the $\mathrm{Bcl}_{2}$ expression in the interstitial cells of Leydig. (Immunostaining DAB, X630)

1-D A computerized photomicrograph of section in the testis of group4 rabbits, showing an over-expression of $\mathrm{Bcl}_{2}$ in the interstitial cells of Leydig. (Immunostaining DAB, X630) 


\section{Plate -2}

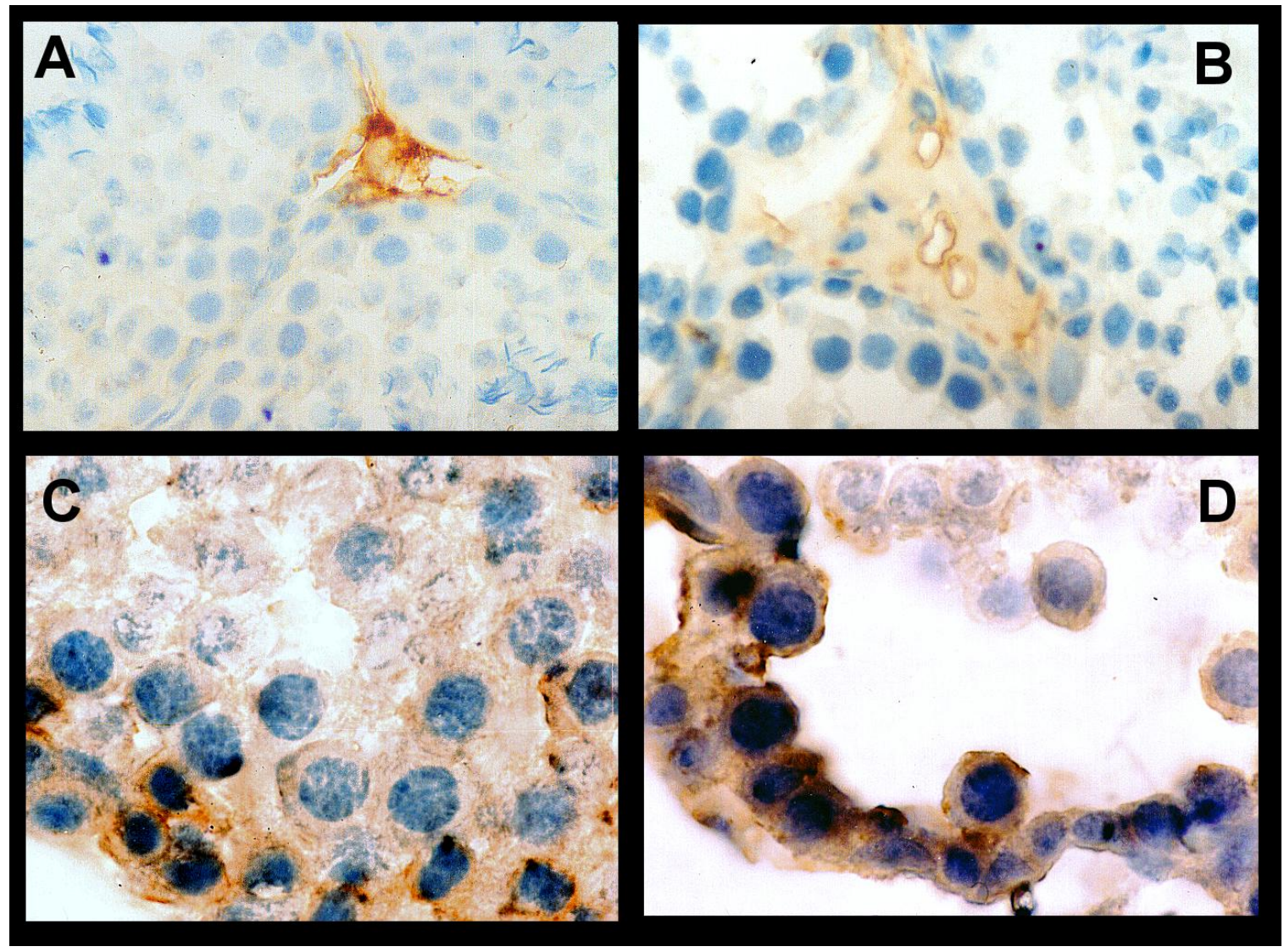

2-A A computerized photomicrograph of section in the testis of recovery group (Group5) rabbits, showing a decrease $\mathbf{B c l}_{2}$ expression in the interstitial cells of Leydig. (Immunostaining DAB, X630)

2-B A computerized photomicrograph of section in the testis of control group rabbits, showing a negative Bcl $_{2}$ expression in the primary spermatocyte cells. (Immunostaining DAB, X630)

2-C A computerized photomicrograph of section in the testis of group 4 rabbits, showing a strong $\mathrm{Bcl}_{2}$ expression in the primary spermatocyte cells. (Immunostaining DAB, X1000)

2-D A computerized photomicrograph of section in the testis of recovery group rabbits, showing a marked $\mathrm{Bcl}_{2}$ expression in the primary spermatocyte cells. (Immunostaining DAB, X1000) 


\section{Discussion}

Apoptosis, spontaneous programmed cell death, has recently generated great interest in several areas of investigation, including infertility.

Each cell is under constant surveillance to maintain the integrity of its genome. Genomic lesions in a cell must be repaired before the onset of DNA replication and cell division. In the scenario that the genomic lesion is not repairable, the damaged cells are disposed in an orderly manner known as programmed cell death or apoptosis. Apoptosis and cell cycle progression are two intimately linked phenomena. Uncontrollable cell proliferation perturbs the cellular homeostasis and this can lead to malignancies, as well as organ dysfunction and developmental abnormalities. The biological pathway controlling cell fate is sequentially organized at the molecular level. A oncogene-derived protein, Bcl-2, confers negative control in the pathway of cellular suicide machinery. A Bcl-2-homologous protein, Bax, promotes cell death by competing with Bcl-2. While Bax-Bax homodimers act as apoptosis inducers, Bcl-2Bax heterodimer formation evokes a survival signal for the cells. Both Bcl-2 and Bax are transcriptional targets for the tumor suppressor protein, p53, which induces cell cycle arrest or apoptosis in response to DNA damage. In all, the coordinate performance of these molecules is crucial for controlling life and death of a cell. (Basu and Haldar . 1998).

Bcl-2 is a widely studied modulator of apoptosis as an integral membrane protein has been localized to several distinct subcellular locations including the outer mitochondrial membrane, perinuclear membrane, and smooth endoplasmic reticulum. Over-expression of the $\mathrm{Bcl}-2$ protein has been shown to prevent or delay many forms of apoptosis induced by a variety of different stimuli, including growth factor deprivation, irradiation, glucocorticoids and chemotherapeutic agents. (Schandl et al, 1999).
In the current work, there was a positive Bcl-2 expression in the interstitial cells of Leydig in all study groups but with different expression. The increase in Bcl-2 expression in Leydig cells was directly proportional with duration of gossypol intake, and this increase did not sustained after cessation of the gossypol intake and showed a statistically significant decrease to level below the control values.

Haider. (2004); recognized two different populations of Leydig cells in rodents and human; fetal and adult. The cells in these two populations are different in ultrastructure, life span, capacity for androgen synthesis, and mechanisms of regulation. Various growth factors modulate Leydig cell differentiation, regeneration, and steroidogenic capacity (e.g. interleukin 1alpha, transforming growth factor beta, inhibin, insulin-like growth factors I and II, vascular endothelial growth factor, and relaxin-like growth factor). Retinol and retinoic acid increase basal testosterone secretion in adult Leydig cells, but decrease it in fetal Leydig cells. Resident macro-phages in the interstitial tissue of the testes are important for differentiation and function of Leydig cells. Apoptosis of Leydig cells is involved in the regulation of Leydig cell number and can be induced by cytotoxins.

Yuan and $X u$ (2003); stated that Apoptosis is necessary for the development and maturation of Leydig cells. However, increased apoptosis results the decline of testosterone production, which may increase germ cell apoptosis and the possibility of infertility. There are several aspects contributing to Leydig cell apoptosis such as ethane dimethanesulphonate (EDS), glucocorticoid, developmental stage and some hormones including $\mathrm{FSH}, \mathrm{LH} / \mathrm{hCG}$ and testosterone. A number of genes are involved in the regulation of Leydig cells apoptosis. It was reported that SCF/c-kit, Bcl-2 and Bcl-xl 


\section{Bassem S. Ahmed and Nasser M. Anwar}

inhibited the apoptosis while caspase-3, Fas, Bax and clusterine stimulated it.

Faria et al. (2003); reported that, the development of Leydig cells in mammals has been widely described as a biphasic pattern with two temporally mature Leydig cell populations, fetal stage followed by the adult generation beginning at puberty. Also they stated that, by examining mouse postnatal Leydig cells by electron micros-copy and in situ DNA fragmentation for apoptosis, showed that cellular death by apoptosis did not occur in Leydig cells during the neonatal, prepubertal, puberty, and adult periods and the remaining fetal Leydig cells in the neonatal testes are associated with the involution or degene-ration processes. In contrast, in the prepubertal and puberty stages, fragment-ation of apoptotic DNA was detected in germ cells present in some seminiferous tubules.

Regarding the effect of gossypol administration on spermatogenesis, the current study showed that there was a negative Bcl-2 expression in the primary spermatocyte cells in the control group rabbits. After 9weeks gossypol oral administration, marked Bcl-2 expression was observed in some primary spermatocyte cells and persisted even after cessation of gossypol for 9 weeks.

Ivan et al, (1997) stated that the early apoptotic wave of germ cells during establishment of spermatogenesis may be required to maintain a proper cell number ratio between maturing germ cells and Sertoli cells. The prevention of an early and massive wave of apoptosis in the testes, which occurs among germinal cells during the first round of spermatogenesis leads to abnormal spermatogenesis accompanied by sterility. The physiological early apoptotic wave in the testis is coincident, in timing and localization, with a temporary high expression of the apoptosis-promoting protein $\mathrm{Bcl}-2$, which disappears at sexual maturity and the intracellular balance between BclxL and Bcl-2 proteins.
Also Knudson et al.(1995); reported that the abnormal spermatogenesis accompanied by sterility occurs as a result from the prevention apoptosis-inhibitory proteins, of a physiological early apoptotic wave, which occurs among germinal cells during the first round of spermatogenesis and which is necessary for the development of normal mature spermatogenesis. This apoptotic wave is concomitant with a temporary high expression of the apoptosis-promoting Bcl-2 protein in germinal cells, which is probably hormonally regulated. That a proper balance between cell death and survival-promoting proteins is critical to achieve this physiological apoptotic wave at an early stage of testicular germinal cell

Hou et al. (2004) reported that gossypol could induce apoptosis in human promyelocytic leukemia cells, as character-rized by DNA fragmentation, polyribose polymerase cleavage. Further molecular analysis showed that gossypol induced the truncation of Bid protein, the loss of mitochondrial membrane potential, cytoch-rome release from mitochondria into cyto-sol, and activation of caspase-3, -8 , and -9 .

Mego. (2002); stated that gossypol is a potential new drug for testicular cancer therapy, because of its spermatotoxic and cytotoxic activity on cell lines derivided from testicular tumors. Gossypol causes suppression of spermatogenesis by an unknown mechanism. It has a non-endocrine inhibiting effect on spermatogenesis, gradual onset of action, and irreversible suppression of spermatogenesis with increasing length of use. It also has an antiproliferative effect on cell lines derived from tumors, mild antineoplastic action in vivo with few side effects. It has mild inhibiting influence on the replication of HIV via possible inhibition of reverse transcriptase HIV. This shows its possible telomerase inhibiting activity.

Teng . (1995); studied the exposure of cultured rat spermatocytes to gossypol acetic acid for five hours, DNA fragmentation in a ladder pattern was found in the medium and 
supernatants of cell lysates. Gossypol was also found to be effective at inhibiting protein kinase C (PKC) activity. Spermatocyte apoptosis induced by gossypol is correlated with the reduction of PKC activity, and that maintenance of PKC basal activity is essential for protecting the spermatocyte from apoptosis.

Shidaifat et al.(1997), demonstrated that gossypol (GP), is a potent inhibitor of malignant human prostate cancer cell growth that acts by arresting cells in G0/G1 phase and that this inhibitory effect may be mediated by transforming growth factor-beta 1 .

Kimura et al. (2003): studied that the apoptotic rate of primary spermatocytes in aged men. They found a significantly elevated compared with that of controls, resulting in a decrease of the number of primary spermatocytes per Sertoli cell. The expression of Bcl-xl was inversely correlated with the apoptotic rate in primary spermatocytes, suggesting that Bcl-xl may be related to the regulation of primary spermatocyte apoptosis. Based on these findings, we conclude that accelerated apoptosis of primary spermatocytes might account for a part of the mechanism of germ cell loss in aging men.

Sinha Hikim, and Hoffer (1987); studied the effects of gossypol on germ cells and Leydig cells in testes of rats made infertile with 10,20 or $30 \mathrm{mg} / \mathrm{kg}$ per day of gossypol for 9 weeks. Numbers of A spermatogonia, preleptotene and pachytene spermatocytes, and step 7 or 8 spermatids per Sertoli cell were counted in stages VII-VIII of the cycle of the seminiferous epithelium. Although high doses $(30 \mathrm{mg} / \mathrm{kg})$ of gossypol produced a significant decrease in the relative number of germ cells compared with vehicletreated controls, no significant deviation in the relative number of germ cells was noted between controls and rats made infertile with 10 or $20 \mathrm{mg} / \mathrm{kg} /$ day of gossypol. No significant deviation in the Leydig cell morphology, cell number, or cell volume was noted as a result of gossypol treatment at the dose levels employed.
Pearce et al. (1986), showed that Gossypol inhibits steroidogenesis in leydig cells by affecting cyclic AMP production at the level of ATP conversion to cyclic AMP.

The study concluded that gossypol has an anti-apoptotic effect on interstitial cells of Leydig, which started after 2 weeks of oral administration and this effect is diminished after cessation of oral intake. Also there was an increase in $\mathrm{Bcl}-2$ protein expression in primary spermatocyte cells after 9weeks of oral gossypol intake and that increase persisted even after cessation of gossypol.

The study recommends further study about the role of gossypol on the relation between apoptotic induced gene and apoptotic inhibiting gene in the testicular tissues.

\section{References}

1. Basu A, and Haldar S. (1998): The relationship between $\mathrm{BcI} 2, \mathrm{Bax}$ and $\mathrm{p} 53$ : consequences for cell cycle progression and cell death. Mol Hum Reprod. Dec;4(12):1099-109.

2. Faria MJ, Simoes ZL, Lunardi LO, and Hartfelder K (2003): Apoptosis process in mouse Leydig cells during postnatal development. Microsc Microanal. Feb;9(1): 68-73.

3. Haider S.G (2004): Cell biology of Leydig cells in the testis. Int Rev Cytol. 233:181-241.

4. Hou DX, Uto T, Tong X, Takeshita T, Tanigawa S, Imamura I, Ose T, Fujii M(2004): Involvement of reactive oxygen species-independent mitochondrial pathway in gossypol-induced apoptosis. Arch Biochem Biophys. 15;428(2):179-87.

5. Ivan Rodriguez, Christiane Ody, Kimi Araki, Irène Garcia and Pierre Vassalli (1997): An early and massive wave of germinal cell apoptosis is required for the development of functional spermatogenesis. The EMBO Journal Vol. 16 No. 9 pp. 22622270

6. Kimura M, Itoh $\mathbf{N}$, Takagi $\mathbf{S}$, Sasao $\mathbf{T}$, Takahashi A, Masumori N, Tsukamoto T. (2003): Balance of apoptosis and proliferation of germ cells related to spermatogenesis in aged men. J Androl. MarApr;24(2):185-91.

7. Knudson CM, Tung KS, Tourtellotte WG, Brown GA, and Korsmeyer SJ., (1995): 


\section{Bassem S. Ahmed and Nasser M. Anwar}

Bax-deficient mice with lymphoid hyperplasia and male germ cell death. Science. Oct 6; 270(5233):96-9.

8. McDonnell, T.J.(1996): Importance of Bcl-2 family in cell death regulation. Experientia, 952-1008.

9. Mego M. (2002): Telomerase inhibitors in anticancer therapy: gossypol as a potential telomerase inhibitor. Bratisl Lek Listy. 2002;103(10):378-81.

10. Minn A.J., Swain R.E., and Thomposon C.B., (1998): Recent progress on the regulation of apoptosis by $\mathrm{Bcl}-2$ family members. Adv. Immunol., 70: 245-279.

11. Pearce S, Sufi SB, O'Shaughnessy PJ, Donaldson A, and Jeffcoate SL (1986): Inhibition by gossypol of cyclic AMP production in mouse Leydig cells. Contraception. 1986 Dec;34(6):639-46.

12. Pezzella F, Tse AG, Cordell JL, Pulford KA, Gatter KC, and Mason DY.. (1990): Expression of the bcl-2 oncogene protein is not specific for the $14 ; 18$ chromosomal translocation. Amer. J. Pathology 137(2): 225-232

13. Savill J., Fadok V., Henson P., and Haslett C., (1999): Phagocytose recognition of cells undergoing apoptosis. Immunology Today, 14: 131-136.

14. Schandl CA, Li S, Re GG, Fan W, and Willingham MC (1999): Mitotic chromosomal bcl-2. I. Stable expression throughout the cell cycle and association with isolated chromosomes. J. Histochem. Cytochem. Pathology 47(2): 139-149

15. Shidaifat F, Canatan H, Kulp SK, Sugimoto Y, Zhang Y, Brueggemeier RW, Somers WJ, Chang WY, Wang HC, Lin YC(1997): Gossypol arrests human benign prostatic hyperplastic cell growth at G0/G1 phase of the cell cycle. Anticancer Res. MarApr;17(2A):1003-9.

16. Sinha Hikim AP, and Hoffer AP (1987): Quantitative analysis of germ cells and Leydig cells in rat made infertile with gossypol. Contraception. 1987 Apr;35(4): 395-408.

17. Teng CS (1995): Gossypol-induced apoptotic DNA fragmentation correlates with inhibited protein kinase $\mathrm{C}$ activity in spermatocytes. Contraception. Dec;52(6):389-95.

18. Yuan SH, and Xu SF. (2003): Leydig cell apoptosis and its regulation. Zhonghua Nan Ke Xue. Jun;9(3):218-20, 225. (Translated from Chinese by MEDLINE). 


\section{دراسة هيستوكيميائية مناعية علي بروتين (ب سي ل2) في خلايا لياج و الخلايا

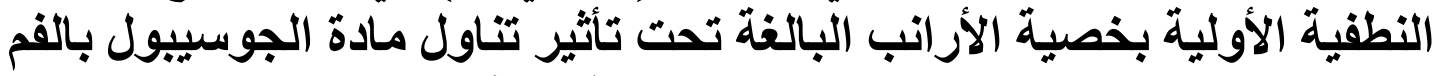

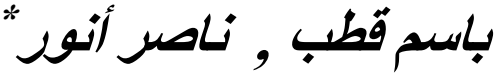

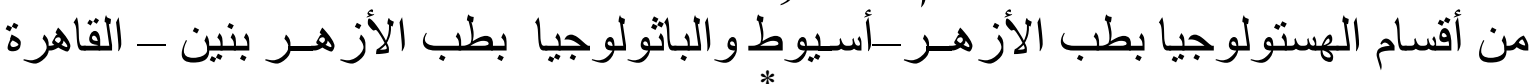

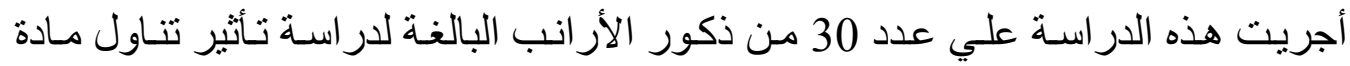

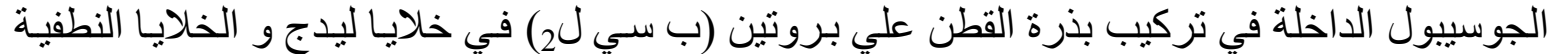

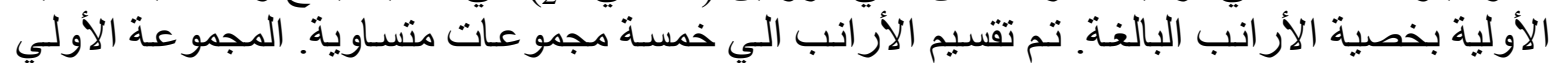

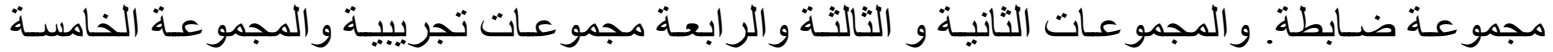

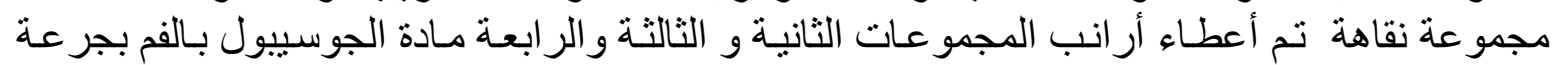

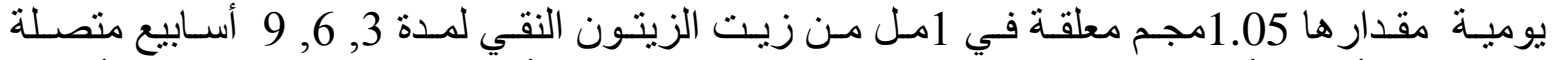
بالترتيب.تم أعطاء أر انب المجمو عة الخامسة نفس الجر عة لمدة 9 أسابيع ثم تم تركهم لمدة 9 أسـابيع أخري لار اسة فترة النقاهة. ونم ذبح الأر انب وأخذ عينة من الخصية وتحضير عينات شمعية وصبغها بالصبغة الهيستو مناعية

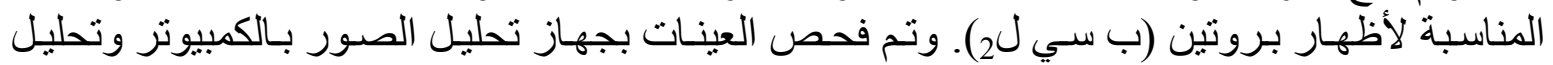
النتائج أحصائيا.

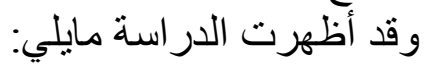
ظهور أيجابي لبروتين (ب سي لـايل) في خلايا ليدج في جميع المجمو عات.

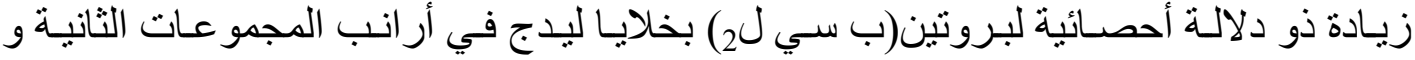

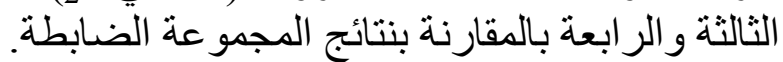

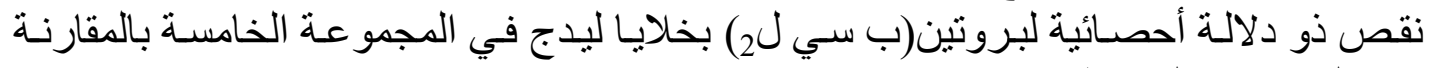
بنتائج المجموعة الضابطة.

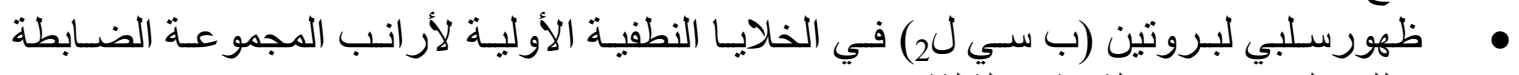
وكذلك المجمو عتين الثانية و الثالثة.

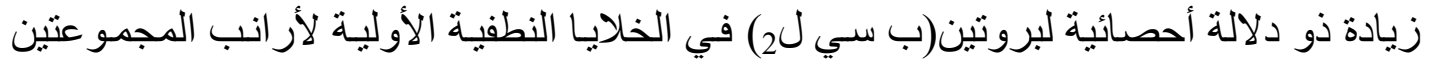

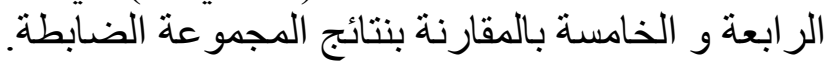

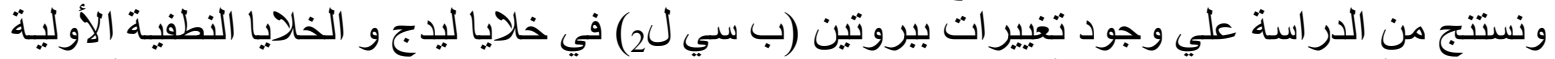

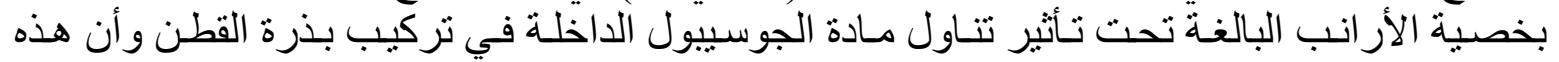

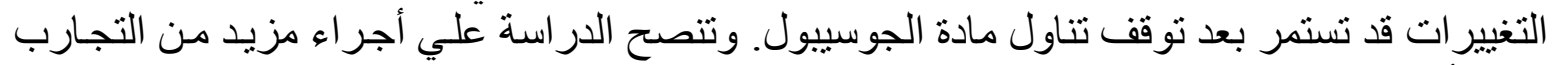
علي تأثثر مادة الجوسييول علي وظائف الخصية. 